Journal of Education and Teaching Learning (JETL)

Volume 3, Issue 1, January 2021

Journal Homepage:

http://pusdikra-publishing.com/index.php/jetl

\title{
Meningkatkan Hasil Belajar Siswa Menggunakan Model Pembelajaran Make A Match Pada Pelajaran IPA Materi Sifat-Sifat Cahaya Di Kelas V SD Negeri 060952 Medan Labuhan T.P. 2019/2020
}

\section{Johannes}

Universitas Terbuka Medan

Corresponding Author johannes@ecampus.ut.ac.id

\begin{tabular}{|c|c|}
\hline & ABSTRACT \\
\hline $\begin{array}{l}\text { ARTICLE INFO } \\
\text { Article history: } \\
\text { Received } \\
\text { 01 January } 2021 \\
\text { Revised } \\
\text { 10 January 2021 } \\
\text { Accepted } \\
\text { 25 January } 2021\end{array}$ & $\begin{array}{l}\text { Penelitian ini dilatar belakangi oleh model pembelajaran yang digunakan } \\
\text { guru tidak sesuai dengan materi pelajaran sehingga menyebabkan } \\
\text { rendahnya minat belajar hasil belajar siswa. Pelaksanaan penelitian ini } \\
\text { bertujuan untuk mendeskripsikan peningkatan hasil belajar belajar siswa } \\
\text { dengan menggunakan strategi pembelajaran make a macth pada mata } \\
\text { pelajaran IPA materi Sifat-Sifat Cahaya kelas V SD Negeri } 060952 \text { Medan } \\
\text { Labuhan. Jenis penelitian ini adalah penelitian tindakan kelas yang } \\
\text { terdiri dari siklus perbaikan pembelajaran. Sebagai subjek penelitian } \\
\text { ditetapkan sebanyak } 30 \text { siswa yang berasal dari siswa kelas V SD Negeri } \\
\text { 060952 Medan Labuhan. Kegiatan penelitian dilakukan pada saat } \\
\text { pembelajaran IPA berlangsung dengan materi Sifat-Sifat Cahaya. Untuk } \\
\text { memperoleh data yang dibutuhkan untuk penelitian ini menggunakan } \\
\text { instrumen test hasil belajar siswa dan kegiatan observasi. Berdasarkan } \\
\text { hasil penelitian maka dapat dikemukakan kesimpulan bahwa dengan } \\
\text { menggunakan model make a macth aktivitas pembelajaran semangkin } \\
\text { meningkat, siswa belajar lebih aktif, pembelajaran berpusat pada guru } \\
\text { sehingga dapat meningkatkan hasil belajar siswa IPA siswa materi Sifat- } \\
\text { Sifat Cahaya di kelas VSD Negeri 060952 Medan Labuhan. }\end{array}$ \\
\hline Key Word & Hasil Belajar, Model, Make a Macth \\
\hline How to cite & $\begin{array}{l}\text { Johannes, Meningkatkan Hasil Belajar Siswa Menggunakan Model } \\
\text { Pembelajaran Make A Match Pada Pelajaran IPA Materi Sifat-Sifat Cahaya } \\
\text { Di Kelas V SD Negeri 060952 Medan Labuhan T.P. 2019/2020, Journal Of } \\
\text { Education And Teaching Learning (Jetl). }\end{array}$ \\
\hline
\end{tabular}

\section{PENDAHULUAN}

Guru sangat berperan penting dalam menumbuhkan minat, motivasi maupun aktivitas siswa dalam meningkuti kegiatan pembelajaran. Tumbuhnya minat, motivasi dan aktivitas belajar tentu akan mendukung keberhasilan proses pembelajaran yang dilaksanakan sehingga dapat meningkatkan hasil belajar siswa.

Berdasarkan hasil wawancara dengan guru yang mengajar IPA di kelas V SD Negeri 060952 Medan Labuhan dapat dikemukakan bahwa sebagian siswa dalam mengikuti pembelajaran minat, motivasi dan aktivitasnya masih rendah. Ini tercermin dari siswa kurang berusaha keras untuk mengerjakan latihan atau tugas yang diberikan guru, siswa jarang bertanya mengenai materi yang 
sedang diajarkan, hanya sedikit siswa yang mencoba menjawab pertanyaan dari guru ketika proses pembelajaran berlangsung, siswa kurang sungguhsungguh memperhatikan penjelasan guru bahkan sebagian siswa terlihat bosan ketika sedang belajar IPA.

Rendahnya minat, motivasi maupun aktivitas belajar siswa tersebut diperkirakan akibat pada saat pembelajaran IPA guru lebih sering menggunakan metode ceramah sehingga guru mendominasi proses pembelajaran dan siswa cenderung pasif. Selain itu, guru menggunakan media pembelajaran yang kurang memotivasi belajar siswa sehingga pembelajaran menjadi kurang menarik. Media pembelajaran harus meningkatkan motivasi siswa. Karena penggunaan media mempunyai tujuan memberikan motivasi kepada siswa. Selain itu media juga harus merangsang siswa mengingat apa yang sudah dipelajari selain memberikan rangsangan belajar baru.

Perlunya dikembangkan pembelajaran yang dapat menumbuhkan minat, motivasi dan keaktifan siswa selama proses belajar mengajar dilaksanakan. Pembelajaran yang efektif tersebut harus diimbangi dengan kemampuan guru dalam menguasai model pembelajaran dan materi yang akan diajarkan. Salah satu alternatif untuk pengajaran tersebut adalah menggunakan model pembelajaran make a match (mencari pasangan). Karena penerapan model pembelajaran make a match akan membentuk minat, motivasi siswa dan keaktifan siswa selama kegiatan pembelajaran di kelas.

Hasil belajar mengandung dua kata atau dua istilah yang memiliki pengertian tertentu satu sama lainnya. Untuk lebih memudahkan dalam memahami kedua kata atau istilah di atas, maka terlebih dahulu akan dikemukakan beberapa pengertian terhadap kata atau istilah dimaksud. Pertama adalah kata belajar. Abdurahman (2010:34) mengemukakan bahwa belajar adalah pengalaman terencana yang membawa perubahan tingkah laku.

Hamalik (2004:27) menegaskan bahwa belajar adalah merupakan proses, suatu kegiatan dan bukan suatu hasil atau tujuan. Belajar bukan hanya mengingat, akan tetapi lebih luas dari itu, yakni mengalami. Syamsudin (2009:157) bahwa belajar adalah suatu proses perubahan prilaku atau pribadi seseorang berdasarkan praktik atau pengalaman tertentu.

Syamsuddin (2009:159) menyatakan bahwa belajar adalah perubahan tingkah laku sebagai akibat dari adanya interaksi antara stimulus dan respon. Dengan kata lain belajar merupakan bentuk perubahan yang dialami siswa dalam hal kemampuan untuk bertingkah laku dengan cara yang baru sebagai hasil interaksi antara stimulus dan respon.

Suryabrata (2012:96) mengidentifikasikan belajar sebagai perubahan tingkah laku sebagai suatu hasil interaksi dengan lingkungannya dalam 
memenuhi kebutuhannya dengan ciri-ciri: perubahan terjadi secara sadar, perubahan dalam belajar terjadi bersifat kontiniu dan fungsional, perubahan dalam belajar bersifat positif dan aktif artinya perubahan itu senantiasa bertambah dan tertuju untuk memperoleh sesuatu yang lebih baik dari sebelumnya, perubahan dalam belajar bukan bersifat sementara, tetapi bersifat permanen, perubahan dalam belajar bertujuan terarah, dan perubahan dalam belajar mencakup seluruh aspek tingkah laku.

Selain kata belajar, maka terdapat istilah atau kata hasil belajar. Beberapa ahli telah banyak memberikan batasan atau defenisi terhadap pengertian hasil belajar. Hasil sesungguhnya adalah yang diperoleh seseorang dari aktivitas belajar yang dilakukannya, hasil ini adalah sebagai wujud bukti perlakuan atau keterlibatan seseorang dalam melakukan usaha belajarnya.

Purwanto (2010:44) mengemukakan pengertian hasil belajar adalah hasil (product) menunjuk pada suatu perolehan akibat dilakukannya suatu aktivitas atau proses belajar yang mengakibatkan berubahnya infut secara fungsional. Hasil produksi adalah perolehan yang didapatkan karena adanya kegiatan mengubah bahan (raw temaals) menjadi bahan jadi (finished goods). Suprijono (2010:5) mengemukakan bahwa hasil belajar adalah pola-pola perbuatan, nilainilai, pengertian-pengertian, sikap-sikap, apresiasi dan keterampilan.

Degeng (2008:89) menyatakan hasil pengajaran atau hasil belajar adalah semua efek yang dapat dijadikan sebagai indicator tentang nilai dari penggunaan metode pengajaran dibawah kondisi yang berbeda. Efek ini bisa berupa efek yang sengaja dirancang karena itu ia efek yang diinginkan, dan bisa juga berupa efek yang nyata sebagai hasil penggunaan metode pengajaran tertentu.

Trianto (2009:49) mengklasifikasikan hasil belajar menjadi lima, yaitu: keterampilan intelektual, yang ditujukan oleh siswa tentang operasi-operasi intelektual yang dapat dilakukan, (model kognitif, merupakan suatu proses control informasi verbal, pengetahuan yang disajikan dalam bentuk proposisi (gagasan) dan bersifat statis, keterampilan motorik, kemampuan yang meliputi kegiatan fisik, penggabungan motorik dengan keterampilan intelektual, sikap, merupakan pembawaan yang dapat dipelajari dan dapat memengaruhi prilaku seseorang terhadap benda-benda, kejadian-kejadian, atau makhluk hidup lainnya.

Model pembelajaran kooperatif tipe mencari pasangan (make a match) yang diperkenalkan Curran (1994). Model pembelajaram kooperatif tipe make a match adalah kegiatan siswa untuk mencari pasangan kartu yang merupakan jawaban soal sebelum batas waktu yang di tentukan habis, siswa yang dapat mencocokkan kartunya akan diberi point dan yang tidak berhasil mencocokkan 
kartunya akan diberi hukuman sesuai dengan yang telah disepakati bersama. Dalam model pembelajaran kooperatif tipe make a match guru membagi siswa satu kelas menjadi 6 kelompok, 2 kelompok memegang kartu soal, 2 kelompok memegang kartu jawaban, dan 2 kelompok jadi tim penilai.

Dengan adanya model pembelajaran kooperatif tipe mencari pasangan (make a match) siswa lebih aktif untuk mengembangkan kemampuan berpikir (Ramadhan, 2008). Disamping itu model pembelajaran kooperatif tipe make a match juga memberi kesempatan kepada siswa untuk bertanya dan mengeluarkan pendapat serta berorientasi dengan siswa yang menjadikan aktif dalam kelas.

Ramadhan (2008) mengemukakan keunggulan model pembelajaran kooperatif tipe mencari pasangan (make a match) adalah sebagai berikut: a) suasana kegembiraan akan tumbuh dalam proses pembelajaran, b) kerja sama antar sesama siswa terwujud dengan dinamis, c) munculnya dinamika gotong royong yang merata di seluruh siswa, d) siswa mencari pasangan sambil belajar mengenai suatu konsep atau topic dalam suasana yang menyenangkan.

Sedangkan kelemahan model pembelajaran kooperatif tipe mencari pasangan (make a match) ini adalah: a) diperlukan bimbingan dari guru untuk melakukan kegiatan, b) waktu yang tersedia perlu dibatasi jangan sampai siswa terlalu banyak bermain-main dalam proses pembelajaran, c) guru perlu persiapan bahan dan alat yang memadai.

Dzaki (2009:121) mengemukakan beberapa kelebihan dan kelemahan dalam menerapkan metode pembelajaran kooperatif. Kelebihan model pembelajaran kooperatif sebagai suatu strategi pembelajaran diantaranya: melalui pembelajaran kooperatif siswa tidak terlalu menggantungkan diri pada guru, akan tetapi dapat menambah kepercayaan kemampuan berfikir sendiri, menemukan informasi dari berbagai sumber, dan belajar dari siswa lain.

Pembelajaran kooperatif dapat mengembangkan kemampuan mengungkapkan idea tau gagasan dengan kata-kata secara verbal dan membandingkannya dengan ide-ide orang lain. Pemebelajaran kooperatif dapat membantu memberdayakan setiap siswa untuk lebih bertanggung jawab dalam belajar. Pembelajaran kooperatif merupakan suatu strategi yang cukup ampuh untuk meningkatkan stasi akademik sekaligus kemampuan social, termasuk mengembangkan harga diri, hubungan interpresional yang positif dengan yang lain, dan sikap positif terhadap sekolah. 
Journal of Education and Teaching Learning (JETL)

Volume 3, Issue 1, January 2021

Page 50-61

\section{METODOLOGI PENELITIAN}

Penelitian ini adalah Penelitian Tindakan Kelas (PTK) yang dilaksanakan menggunakan siklus yang merupakan tindakan perbaikan dalam pelaksanaan pembelajaran yang lebih baik. Tiap pelaksanaan siklus terdiri dari perencanaan, pelaksanaan, tindakan, observasi dan refleksi. Penelitian dilakukan pada siswa kelas V SD Negeri 060952 Medan Labuhan dan waktu pelaksanaan penelitian tindakan kelas Tahun Pelajaran 2019/2020. Sebagai subjek dalam penelitian ini adalah siswa kelas V SD Negeri 060952 Medan Labuhan Tahun Pelajaran 2019/2020 sebanyak satu kelas yang berjumlah 30 siswa. Objek penelitian tindakan kelas ini adalah penggunaan model pembelajaran make a match dalam meningkatkan hasil belajar IPA materi sifat-sifat cahaya. Untuk mengumpulkan data yang dibutuhkan dalam penelitian ini menggunakan alat pengumpul data yaitu lembar observasi adalah format penilaian terhadap pelaksanaan kegiatan selama pembelajaran berlangsung. Format lembar observasi terdiri dari aAktivitas siswa dalam belajar dan aktivitas guru mengajar

Tes terdiri dua tahapan pelaksanaan yaitu atas tes kemamapuan awal dan tes hasil belajar. Tes kemampuan awal berisikan soal-soal yang berkaitan dengan materi yang menuntut kemampuan siswa. Tes kemampuan awal diberikan untuk mengetahui sejauh mana tingkat penguasaan siswa terhadap materi, dan mengetahui bentuk kesulitan belajar yang dialami oleh siswa. Tes awal diberikan sebelum pemberian tindakan. Tes hasil belajar juga berisikan soal-soal yang berkaitan dengan materi yang diambil dari LKS dan dilakukan validitas sehingga tes yang dinyatakan valid. Tes diberikan bertujuan untuk mengetahui apakah kemampuan siswa akan meningkat setelah pengajaran dengan diberikannya pada mata pelajaran IPA materi sifat-sifat cahaya. Teknik analisa yang dipergunakan sesuai dengan data yang dikumpulkan. Data penelitian ini dianalisis dengan menggunakan teknik analisis berupa kegiatan catatan lapangan yang disajikan secara lengkap selama proses penelitian berlangsung. Analisis data diperoleh berdasarkan hasil observasi, evaluasi hasil belajar siswa, refleksi dari tiap-tiap siklus yang dilakukan.

Teknik analisa data yang dilakukan dalam penelitian ini adalah berkaitan dengan ketuntasan belajar siswa dan hasil observasi selama pelaksanaan kegiatan pembelajaran dilaksanakan. Teknik analisa data adalah dengan pengukuran terhadap kegiatan pembelajaran yaitu daya serap individu dan daya serap klasikal. Hasil observasi dianalsisi secara deskriptif dan proses pembelajaran dikatakan efektif jika pelaksanaan pembelajaran minimal berjalan deangn baik. Obervasi aktifitas belajar siswa dan aktivitas kegiatan guru yang 
Journal of Education and Teaching Learning (JETL)

Volume 3, Issue 1, January 2021

Page 50-61

dilakukan peneliti. Menganalisis lembar observasi dengan kriteria sebagai berikut :

Tabel 1. Kategori Penilaian Hasil Observasi

\begin{tabular}{ll}
\hline Nilai & Kategori \\
\hline $90 \%-100 \%$ & Sangat tinggi \\
$80 \%-89 \%$ & Tinggi \\
$65 \%-79 \%$ & Sedang \\
$55 \%-64 \%$ & Rendah \\
$0 \%-54 \%$ & Sangat rendah \\
\hline
\end{tabular}

\section{HASIL PENLITIAN DAN PEMBAHASAN}

Berdasarkan hasil pre test kemampuan awal siswa selanjutnya dapat dikemukakan persentase tingkat hasil belajar berdasarkan pre tes sebagai berikut: Tingkat ketuntasan individu (daya serap individu) dapat dikemukakan pada tabel sebagai berikut:

Tabel 2. Hasil Ketuntasan Belajar Individu Siswa Pada Pre Test

\begin{tabular}{|c|c|c|c|l|}
\hline No & Kriteria & Frekuensi & Persentase & Ketuntasan Individu \\
\hline 1 & $<65$ & 30 & $100,00 \%$ & Tidak Tuntas \\
\hline 2 & $\geq 65$ & 0 & $00,00 \%$ & Tuntas \\
\hline \multicolumn{2}{r|}{ Jumlah } & 30 & $100,00 \%$ & \\
\hline
\end{tabular}

Berdasarkan tabel di atas dapat dikemukakan ketuntasan individu (daya serap individu) berdasarkan hasil pre tes siswa yaitu sebanyak 30 orang siswa $(100,00 \%)$ memperoleh nilai < 65 dan dinyatakan tidak mengalami ketuntasan belajar secara individu.

Untuk mengetahui tingkat ketuntasan belajar siswa secara klasikal dapat dikemukakan pada tabelsebagai berikut:

Tabel 3. Hasil Ketuntasan Belajar Klasikal Siswa Pada Pre Test

\begin{tabular}{|c|c|c|c|c|}
\hline No & Tuntas & Frekuensi & Persentase & Ketuntasan Klasikal \\
\hline 1 & Tuntas & 0 & $00,00 \%$ & $00,00 \%$ \\
\hline 2 & Tidak Tuntas & 30 & $100,00 \%$ & \\
\hline \multicolumn{2}{|c|}{ Jumlah } & 30 & $100,00 \%$ & \\
\hline
\end{tabular}

Secara umum kesulitan belajar berdasarkan hasil pre test siswa dapat dikemukakan yaitu siswa kurang memahami tentang materi sifat-sifat cahaya, kurang mampu memahami bentuk-bentuk materi sifat-sifat cahaya, dan siswa kurang memahami pentingnya materi sifat-sifat cahaya. 
Journal of Education and Teaching Learning (JETL)

Volume 3, Issue 1, January 2021

Page 50-61

Tingkat ketuntasan belajar individu dapat dikemukakan pada tabel sebagai berikut:

Tabel 4. Hasil Tes Ketuntasan Belajar Individu Siswa Pada Siklus I

\begin{tabular}{|c|c|c|c|l|}
\hline No & Kriteria & Frekuensi & Persentase & Ketuntasan Individu \\
\hline 1 & $<65$ & 16 & $53,33 \%$ & Tidak Tuntas \\
\hline 2 & $\geq 65$ & 14 & $46,67 \%$ & Tuntas \\
\hline \multicolumn{2}{|c|}{ Jumlah } & 30 & $100,00 \%$ & \\
\hline
\end{tabular}

Berdasarkan tabel di atas diketahui ketuntasan belajar individu berdasarkan hasil tes siswa pada siklus I yaitu sebanyak 14 siswa $(46,67 \%)$ memperoleh nilai $\geq 65$ dan telah mengalami ketuntasan belajar secara individu, sebanyak 16 siswa (53,33\%) siswa tidak mengalami ketuntasan belajar secara individu. Dengan demikian hasil tes pada siklus I membuktikan bahwa siswa belum mengalami ketuntasan secara individu sehingga perlu dilakukan tindakan perbaikan melalui sikklus selanjutnya.

Berdasarkan hasil tes belajar siswa selanjutnya dapat diketahui tingkat ketuntasan belajar siswa secara klasikal. Untuk mengetahui tingkat ketuntasan belajar siswa secara klasikal dapat dikemukakan pada tabel sebagai berikut:

Tabel 5. Hasil Tes Ketuntasan Belajar Klasikal Siswa Pada Siklus I

\begin{tabular}{|c|c|c|c|c|}
\hline No & Tuntas & Frekuensi & Persentase & Ketuntasan Klasikal \\
\hline 1 & Tuntas & 14 & $46,67 \%$ & $46,67 \%$ \\
\hline 2 & Tidak Tuntas & 16 & $53,33 \%$ & \\
\hline \multicolumn{2}{|c|}{ Jumlah } & 30 & $100,00 \%$ & \\
\hline
\end{tabular}

Berdasarkan tabel di atas dapat diketahui bahwa sebesar $46,67 \%$ siswa sudah mengalami ketuntasan individu, sebesar 53,33\% belum mengalami ketuntasan individu dan ketuntasan klasikal sebesar 46,67\%. Hal ini membuktikan bahwa secara klasikal belum mengalami ketuntasan belajar karena belum mencapai 80,00\% tingkat ketuntasan klasikal.

Tingkat ketuntasan individu (daya serap individu) dapat dikemukakan pada tabel sebagai berikut: 
Journal of Education and Teaching Learning (JETL)

Volume 3, Issue 1, January 2021

Page 50-61

Tabel 6. Hasil Tes Ketuntasan Belajar Individu Siswa Pada Siklus II

\begin{tabular}{|c|c|c|c|l|}
\hline No & Kriteria & Frekuensi & Persentase & Ketuntasan Individu \\
\hline 1 & $<65$ & 2 & $6,67 \%$ & Tidak Tuntas \\
\hline 2 & $\geq 65$ & 28 & $93,33 \%$ & Tuntas \\
\hline \multicolumn{2}{|c|}{ Jumlah } & 30 & $100,00 \%$ & \\
\hline
\end{tabular}

Berdasarkan tabel di atas dapat dikemukakan ketuntasan individu (daya serap individu) berdasarkan hasil tes siswa pada siklus II yaitu sebanyak 28 orang siswa $(93,33 \%)$ memperoleh nilai $\geq 65$ dan dinyatakan telah mengalami ketuntasan individu, sebanyak 2 orang siswa $(7,67 \%)$ siswa tidak mengalami ketuntasan belajar secara individu.

Berdasarkan hasil tes belajar siswa selanjutnya dapat diketahui tingkat ketuntasan belajar siswa secara klasikal. Untuk mengetahui tingkat ketuntasan belajar siswa secara klasikal dapat dikemukakan pada tabel sebagai berikut:

Tabel 7. Hasil Tes Ketuntasan Belajar Klasikal Siswa Pada Siklus II

\begin{tabular}{|c|c|c|c|c|}
\hline No & Tuntas & Frekuensi & Persentase & Ketuntasan Klasikal \\
\hline 1 & Tuntas & 28 & $93,33 \%$ & $93,33 \%$ \\
\hline 2 & Tidak Tuntas & 2 & $6,67 \%$ & \\
\hline \multicolumn{2}{|c|}{ Jumlah } & 30 & $100,00 \%$ & \\
\hline
\end{tabular}

Berdasarkan tabel di atas dapat diketahui bahwa sebesar 92,31\% siswa sudah mengalami ketuntasan klasikal, dan sebesar 7,69\% belum mengalami ketuntasan klasikal sebesar 57,69\%. Hal ini membuktikan bahwa secara klasikal sudah mengalami ketuntasan belajar karena sudah mencapai 80,00\% tingkat ketuntasan klasikal.

Selanjutnya dapat dikemukakan tabel ketuntasan hasil belajar siswa secara klasikal pada tabel sebagai berikut:

Tabel 8. Ketuntasan Belajar Siswa Secara Klasikal

\begin{tabular}{|c|c|c|}
\hline No & Pelaksanaan Test & Persentase Ketuntasan Klasikal \\
\hline 1 & Pre Test & $0,00 \%$ \\
\hline 2 & Siklus I & $46,67 \%$ \\
\hline 3 & Siklus II & $93,33 \%$ \\
\hline
\end{tabular}


Berdasarkan tabel di atas dapat dikemukakan bahwa pada pelaksanaan pre tes diketahui hasil ketuntasan belajar siswa secara klasikal sebesar 0,00\%, kemudian mengalami peningkatan setelah dilakukannya pelaksanaan pembelajaran siklus I dimana diperoleh ketuntasan belajar klasikal sebesar $46,67 \%$ sehingga belum mengalami ketuntasan secara klasikal karena tidak mencapai ketuntasan sebesar 80,00\% kemudian mengalami peningkatan setelah pelaksanaan pembelajaran siklus II dengan perolehan ketuntasan hasil belajar individu sebesar 93,33\% dan dinyatakan mengalami ketuntasan klasikal karena sudah mencapai $80,00 \%$. Selanjutnya dapat dikemukakan grafik ketuntasan klasikal siswa siswa sebagai berikut:

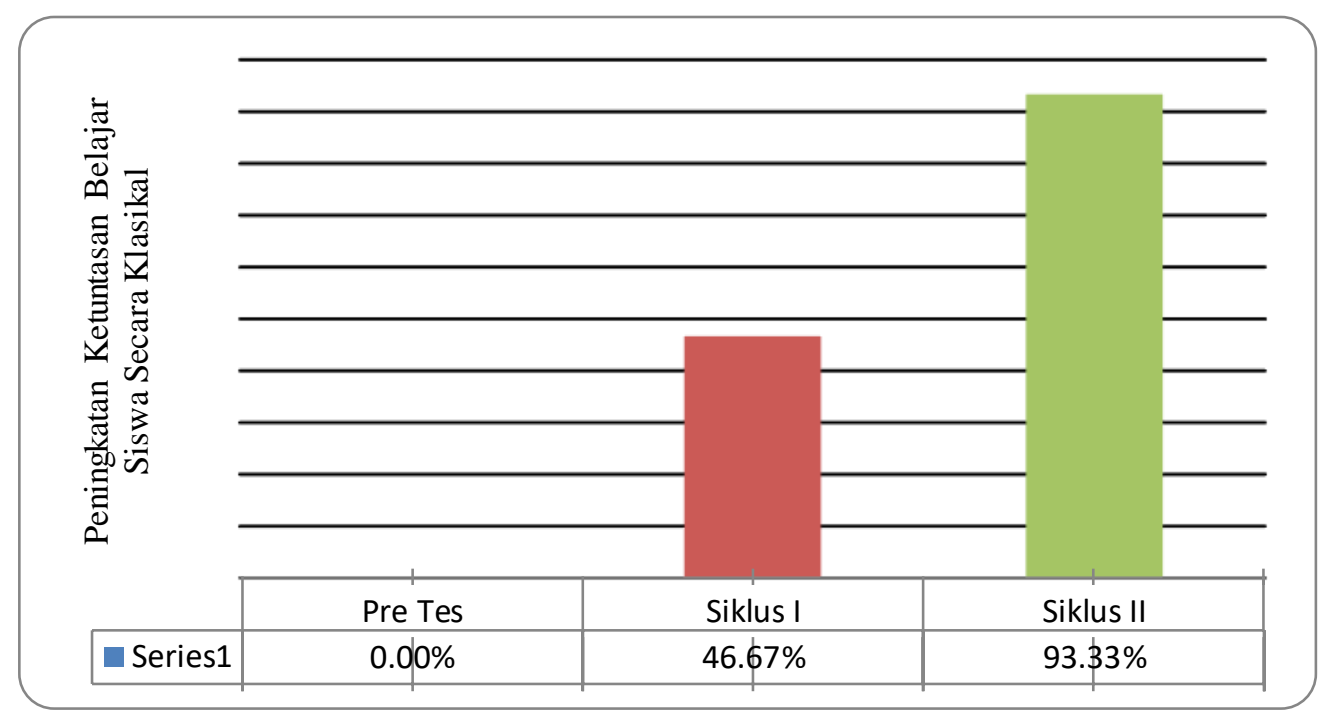

Gambar 1. Diagram Batang Peningkatan Ketuntasan Belajar Klasikal

Berikut dikemukakan tabel peningkatan ketuntasan hasil belajar siswa secara individu pada pelajaran IPA materi sifat-sifat cahaya dengan menggunakan strategi pembelajaran make a macth .

Tabel 9. Tabel Ketuntasan Hasil Belajar Siswa Secara Individu

\begin{tabular}{|c|c|c|c|}
\hline \multirow{2}{*}{ No } & \multirow{2}{*}{ Pelaksanaan Test } & Persentase Ketuntasan Individu \\
\cline { 3 - 4 } & Pre Tes & $100.00 \%$ & Tuntas \\
\hline 1 & Siklus I & $53.33 \%$ & $0.00 \%$ \\
\hline 2 & Siklus II & $6.67 \%$ & $46.67 \%$ \\
\hline 3 & & & $93.33 \%$ \\
\hline
\end{tabular}

Berdasarkan tabel di atas dapat dikemukakan bahwa pada pelaksanaan pre tes diketahui hasil ketuntasan belajar siswa sebesar 0,00\%, kemudian mengalami peningkatan setelah dilakukannya pelaksanaan pembelajaran 
Journal of Education and Teaching Learning (JETL)

Volume 3, Issue 1, January 2021

Page 50-61

dengan siklus I dimana diperoleh ketuntasan belajar individu sebesar 46,67\% dan mengalami peningkatan setelah pelaksanaan pembelajaran siklus II dengan perolehan ketuntasan hasil belajar indivisu sebesar 93,33\%. Selanjutnya dapat dikemukakan grafik ketuntasan individu siswa sebagai berikut:

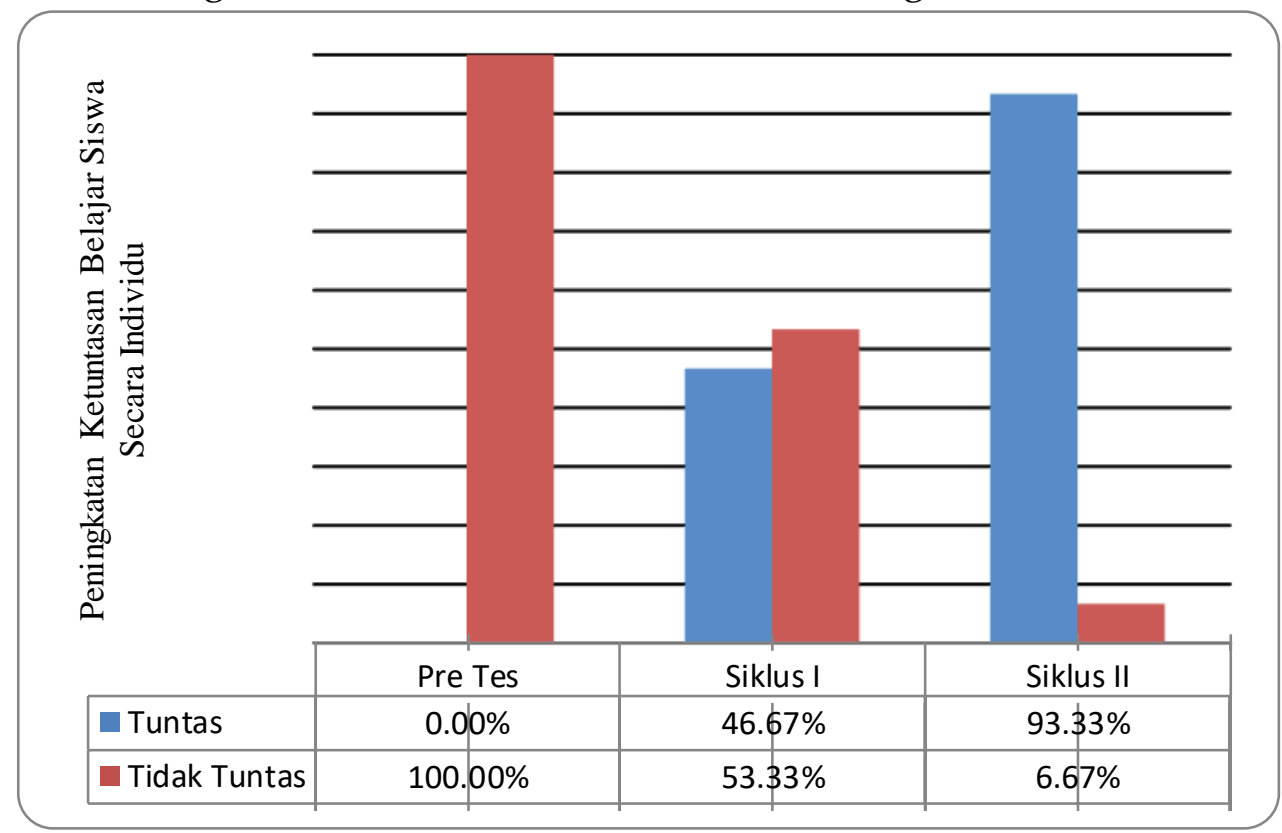

Gambar 2. Diagram Batang Peningkatan Ketuntasan Belajar Individu

Berikut disajikan tabel peningkatan rata-rata hasil belajar siswa selama pelaksanaan pembelajaran IPA materi sifat-sifat cahaya dengan menggunakan strategi pembelajaran make a macth.

Tabel 10. Peningkatan Rata-Rata Hasil Belajar Siswa

\begin{tabular}{|c|c|c|}
\hline No & Pelaksanaan Test & Rerata \\
\hline 1 & Pre Test & 43,17 \\
\hline 2 & Siklus I & 66,50 \\
\hline 3 & Siklus II & 86,33 \\
\hline
\end{tabular}

Berdasarkan tabel di atas dapat dikemukakan bahwa pada pelaksanaan pre tes diketahui hasil rata-rata hasil belajar siswa sebesar 43,17, kemudian mengalami peningkatan setelah dilakukannya pelaksanaan pembelajaran dengan siklus I dimana diperoleh rata-rata hasil belajar sebesar 66,50 dan mengalami peningkatan setelah pelaksanaan pembelajaran siklus II dengan perolehan rata-rata hasil belajar sebesar 86,33 Selanjutnya dapat dikemukakan grafik peningtakan rata-rata hasil belajar siswa sebagai berikut: 


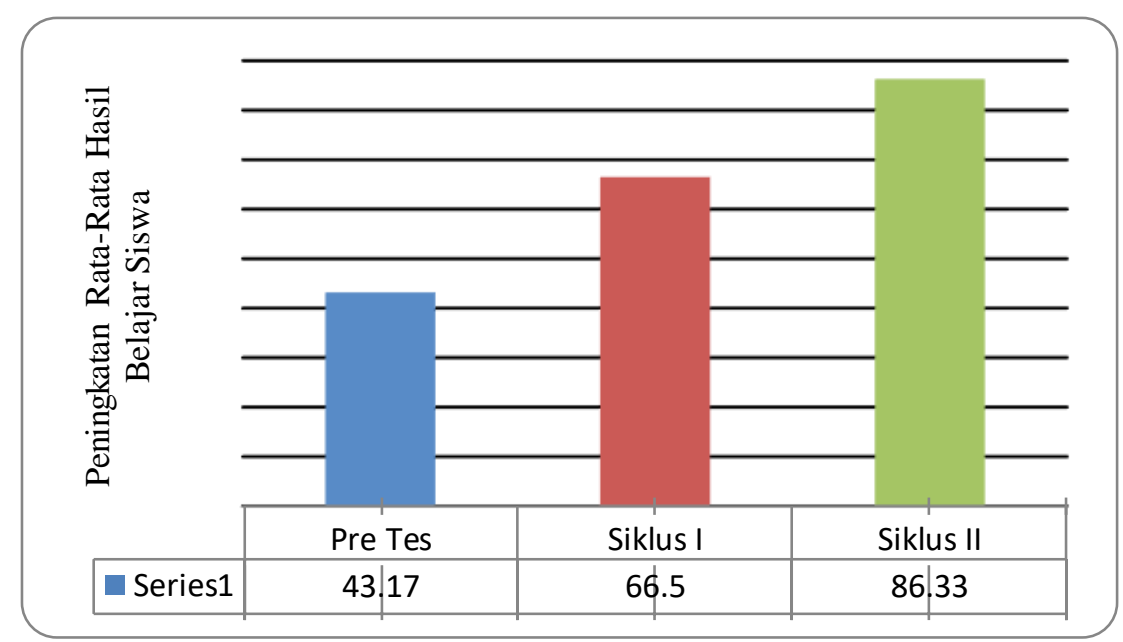

Gambar 3. Diagram Batang Peningkatan Rata-Rata Hasil Belajar Siswa

\section{KESIMPULAN}

Berdasarkan hasil penelitian dan pembahasan yang telah dikemukakan sebelumnya, maka dapat dikemukakan kesimpulan bahwa penggunaan model pembelajaran make a match dapat meningkatkan hasil belajar siswa pada mata pelajaran IPA materi sifat-sifat cahaya di kelas V SD Negeri 060952 Medan Labuhan.

Berdasarkan hasil temuan dan kesimpulan di atas, maka dapat dikemukakan saran sebagai berikut:

1. Kepala Sekolah SD Negeri 060952 Medan Labuhan untuk lebih memberikan perhatian terhadap penyelenggaraan pendidikan di sekolah guna meningkatkan kemampuan guru melaksanakan tugas mengajar.

2. Para guru di SD Negeri 060952 Medan Labuhan berusaha untuk meningkatkan keterampilan mengajar dengan mengikuti berbagai pelatihan guna meningkatkan kemampuan melaksanakan tugas mengajar.

3. Bagi siswa SD Negeri 060952 Medan Labuhan untuk lebih aktif dalam mengikuti kegiatan belajar guna meningkatkan hasil belajar.

\section{DAFTAR PUSTAKA}

Abdurrahman, M. 2003. Pendidikan Bagi Anak Berkesulitan Belajar. Jakarta: Rineka Cipta.

Ani, CT. 2006. Pengaruh Motivasi Belajar Terhadap Hasil Belajar. Jakarta: Rineka Cipta.

Azmiyawati, Choiril, dkk. 2008. IPA 5 Salingtemas. Jakarta: Intan Pariwara.

Dimyati dan Mudjiono.1994. Belajar dan Pembelajaran. Jakarta: Rineka Cipta. 
Djamamrah. S.B. dan Zain. 2006. Strategi Belajar Mengajar. Jakarta: Rineka Cipta. Hamalik, Oemar. 2004. Proses Belajar Mengajar. Jakarta: Bumi Aksara.

Kemmis,S. and Mc Taggert,R.,eds.1988. The action research planner,third edition. Victoria : Deakin University.

Kholilah Elfi. 2012. Upaya Meningkatkan Hasil Belajar IPA Dan Aktifitas Siswa Dengan Menggunaqkan Model Kooperatif Tipe Make A Match Pada Pokok Bahasan Pecahan Di Kelas VII SMPN 22 Medan T.A 2010/2011.

Kurniawati Indah. 2011. Implementasi Model Pembelajaran Make A Match Pada Materi Perilaku Menyimpang Kelas X-7 MAN 1 Pekalongan T.A 2009/2010.

Lie, A. 2004. Cooperative Learning. Jakarta: Gramedia Widiasarana Indonesia.

Nashar. 2004. Pengaruh Motivasi Belajar Terhadap Hasil Belajar. Jakarta : Delia Press

Natawidjaja. 1979. Psikologi Pendidikan. Bandung: Remadja Rosdakarya.

Rafi Udin. 1997. Rancangan Penelitian Tindakan. Bandung: Remaja Rosdakarya.

Sardiman, A. M. 2006. Interaksi dan Motivasi Belajar Mengajar. Jakarta: Rajawali Press.

Slameto. 2002. Belajar dan Faktor - Fakktor yang Mempengaruhinya. Jakarta: Rineka Cipta.

Soemanto.1989. Psikologi Pendidikan. Jakarta : Rineka Cipta.

Sudjana. 2005. Metoda Statistika. Bandung: Tarsito. 